\title{
Geeni siittiöiden puolihäntävian takana
}

\author{
Anu Sironen ${ }^{1}$, Bo Thomsen ${ }^{4}$, Magnus Andersson ${ }^{2}$, Virpi Ahola ${ }^{3}$, Johanna Vilkki ${ }^{1}$ \\ ${ }^{1}$ MTT Maa- ja elintarviketalouden tutkimuskeskus, Kotieläintuotannon tutkimus, Eläinjalostus, 31600 \\ Jokioinen \\ ${ }^{2}$ Eläinlääketieteellinen tiedekunta, Helsingin Yliopisto, 04920 Saarentaus \\ ${ }^{3}$ MTT Maa- ja Elintarviketalouden Tutkimuskeskus, Elintarvikkeiden tutkimus, 31600 Jokioinen \\ ${ }^{4}$ Danish Institute of Agricultural Sciences, PO Box 50, Tjele DK-8830, Tanska
}

\section{Tiivistelmä}

Siittiöiden puolihäntävika havaittiin ensimmäisen kerran 1987. Vuonna 1998 oireesta tuli huomattava tuotannollinen ongelma, kun se havaittiin yhdeksässä jalostukseen käytettävässä karjussa. Karjujen siittiöiden hännän pituus on huomattavasti lyhentynyt, siittiömäärä on alentunut ja siittiöt ovat täysin liikkumattomia (Andersson et al. 2000). Karjujen epämuodostuneet siittiöt on nimetty sytologisten tutkimusten yhteydessä puolihäntäisiksi siittiöiksi. Siittiöiden puolihäntäisyys aiheuttava geenivirhe näyttää vaikuttavan ainoastaan siittiöiden muodostukseen, koska sairailta karjuilta ei ole löydetty muita oireita ja myös naaraat on todettu terveiksi.

Siittiöiden puolihäntäsyndrooman paikantamiseksi sian genomi kartoitettiin noin 10 cM:n välein käyttäen 258 mikrosatelliittimarkkeria Kartoituksessa käytettiin kahta eri ryhmää, sairaista ja terveistä verrokeista koostuvaa, joista haettiin sairauteen liittyvää homotsygotiaa sairaista yksilöistä verrattuna terveisiin. Kartoituksessa löydettiin kolme markkeria sisältävä kromosomialue, joka selvästi kytkeytyi sairauteen. Vertailemalla kaikkien sairaiden haplotyyppejä keskenään voitiin oireen taustalla vaikuttavan geenin sijainti rajata $3 \mathrm{cM}: n$ alueelle kahden markkerin välille. Jotta riittävä erotuskyky markkeriavusteista valintaa ja kandidaattigeenien etsimistä varten saavutettaisiin, täytyi kromosomaalista aluetta rajata.

Oireeseen kytkeytyvää aluetta rajaavilla markkereilla poimittujen BAC-kloonien sisältämää sian genomista emäsjärjestystä verrattiin ihmisen sekvenssitietokantaan. Sialla oireeseen kytkeytynyttä aluetta vastasi 2 Mbp:n alue ihmisen kromosomissa 5. Yhteistyössä tanskalaisen tutkimuskeskuksen (Danish Institute of Agricultural Sciences, DIAS) kanssa poimittiin heidän tietokannastaan sian sekvenssejä tällä alueella sijaitsevien ihmisen tunnettujen geenien avulla. Näistä sian geeneistä etsittiin sekvenssimuuntelua sekvensoimalla terveitä ja sairaita yksilöitä. Sekvenssimuuntelun ja sairaissa kromosomeissa havaittujen rekombinaatioiden perusteella oire pystyttiin rajaamaan vain muutaman geenin alueelle ihmisen geenikartalla. Näistä yksi, siittiön hännän muodostuksessa ilmenevä geeni, oli varteenotettava oireen kandidaattigeeni. Kandidaattigeenin mRNA sekvensoitiin ja havaittiin yhden eksonin puutos sairailla yksilöillä verrattuna terveisiin. Sairaiden yksilöiden DNA:ta sekvensoimalla löydettiin retrovirusinsertio puuttuvan eksonin jälkeisestä intronista. Sairailta yksilöiltä löydettiin myös toinen virheellisesti silmukoitu RNA tuote, jossa puuttuva eksoni oli mukana, mutta lisäksi siihen oli liitetty osa inserttiä. Nämä molemmat muutokset geenin lukukehyksessä johtavat ennenaikaiseen translaation lopetukseen. Geenin ekspressiota on myös alustavasti tutkittu ja puuttuva eksoni näyttää ilmentyvän vain testiksessä, mikä on odotettavaa, koska sairailla karjuilla ei havaita muita oireita ja homotsygootit emakot ovat terveitä.

Geeni, puolihäntävika, siittiö, sika 


\section{Johdanto}

Suomalaisessa Yorkshire-sikarodussa on 1980-luvulta lähtien ilmennyt siittiöiden liikkumattomuudesta ja puolihäntäisyydestä johtuvaa hedelmättömyyttä. Ensimmäinen tapaus havaittiin 1987. Vuonna 1998 oireesta tuli huomattava tuotannollinen ongelma, kun se havaittiin yhdeksässä jalostukseen käytettävässä karjussa ja vuonna 1999 löydettiin jo 19 oireen takia steriiliä karjua. Karjujen siittiöiden hännän pituus on huomattavasti lyhentynyt, siittiömäärä on alentunut ja siittiöt ovat täysin liikkumattomia (Andersson et al. 2000). Karjujen epämuodostuneet siittiöt on nimetty sytologisten tutkimusten yhteydessä puolihäntäisiksi siittiöiksi. Suomalaisessa Yorkshiresikakannassa siittiöiden puolihäntäisyyttä aiheuttavan geenivirheen voidaan olettaa vaikuttavan ainoastaan siittiöiden muodostukseen, koska sairailta karjuilta ei ole löydetty muita oireita ja myös naaraat on todettu terveiksi.

Tutkimuksen tarkoituksena on löytää taudin aiheuttava geenivirhe ja 100\%:nen geenitesti markkeriavusteista valintaa varten. Suomalaisessa Yorkshire-sikakannassa on ollut vuodesta 2001 alkaen käytössä DNA-testi, jota on käytetty markkeriavusteissessa valinnassa (MAS, marker assisted selection), mutta testi ei ole $100 \%$ ja tuloksen tulkitsemiseksi tarvitaan myös testattavan yksilön vanhempien näytteet. Siittiöiden puolihäntävian taustalla olevan geenin löytyminen voi myös auttaa ymmärtämään siittiön flagellan kehitystä ja selittämään muiden lajien samankaltaisia oireita.

\section{Menetelmät}

Homotsygotiakartoituksessa käytettiin 228:a mikrosatelliittimarkkeria (U.S Pig Genome Coordination Program), jotka kattoivat sian autosomaalisen kromosomiston noin 10 cM:n välein. Kartoituksessa käytettiin kahta eri ryhmää, sairaista ja terveistä verrokeista koostuvaa, joista haettiin sairauteen liittyvää homotsygotiaa sairaista yksilöistä verrattuna terveisiin. PCR-reaktiot sisälsivät 50 ng DNA:ta, 1 yksikön Dynazyme DNA-polymeraasia (Finnzymes, http://www.finnzymes.fi/) entsyymin valmistajan toimittamassa puskurissa, $0.2 \mathrm{mM}$ jokaista dNTP:tä ja 10 pmol jokaista oligonukleotidialuketta $30 \mu \mathrm{l}: n$ kokonaistilavuudessa. Syklejä PCR-reaktiossa oli $30\left(94^{\circ} \mathrm{C}, 1 \mathrm{~min}\right.$; $\left.58^{\circ} \mathrm{C}, 1 \mathrm{~min} ; 72^{\circ} \mathrm{C}, 1 \mathrm{~min}\right)$ PCR tuotteet eroteltiin elektroforeesilla 5\%:lla denaturoivalla polyakryyliamidigeelillä (7M urea) Alleelikoot määritettiin ABI GENOTYPER (2.1)-ohjelmalla ja kokostandardina käytettiin TAMRA GeneScan 350. Markkerit, jotka osoittivat homotsygotian lisääntymistä sairaspoolissa analysoitiin tyypittämällä yksilönäytteet ja kytkentäanalyysi suoritettiin Genehunter-ohjelmalla (Kruglyak et al. 1996).

Hienokartoitusta varten BAC-klooneja poimittiin oireeseen kytkeytyneillä markkereilla PCR:än perustuvalla menetelmällä. Valitut kloonit esikasvatettiin $5 \mathrm{ml}$ antibiootin sisältävässä LBmediumissa $\left(8 \mathrm{~h} 37^{\circ} \mathrm{C}\right)$ ja varsinainen kasvatus tehtiin $100 \mathrm{ml}$ :ssa $14 \mathrm{~h}$ kuten edellä. BAC DNA eristettiin Qiagen plasmid midi kit (http://www1.qiagen.com/). PCR-reaktiot tehtiin kuten edellä käyttäen $1 \mu l$ BAC DNA.

Ekspressiotutkimusta ja kandidaattigeenin sekvensointia varten eristettiin RNA kudosnäytteistä (säilytetty RNAlater-puskurissa, Qiagen) RNeasy Protect Mini ja Midi kiteillä (Qiagen). RNA käännettiin cDNA:ksi RT-PCR-kiteillä (SuperScript, Invitrogen, http://www.invitrogen.com ja ImProm-II Reverse Transcription System, Promega, http://www.promega.com) valmistajan ohjeiden mukaan. PCR-reaktioihin käytettiin 0.5 $\mu$ l cDNA:ta.

Sekvensointia varten PCR-tuotteet puhdistettiin ExoSAP-IT ${ }^{\mathrm{TM}}$-kitillä (Amersham Biosciences, http://www5.amershambiosciences.com) ja sekvensointiin käytettiin samoja alukkeita kuin PCR:ssä. BAC-päät sekvensoitiin T7- ja SP6-alukkeilla. Sekvensointiin käytettiin MegaBace 500-laitetta (Amersham Biosciences) ja DYEnamic ET Terminator-kittiä sekä Thermo Sequenase ${ }^{\mathrm{TM}}$ II DNApolymeraasia (Amersham Biosciences). 


\section{Tulokset ja tulosten tarkastelu}

Homotsygotiakartoituksella selvitettiin, millä kromosomialueella oireen aiheuttava lokus sijaitsee. Kartoituksessa löydettiin yksi kromosomialue, joka selvästi kytkeytyi sairauteen. Tämä alue sisälsi kolme markkeria, joiden haplotyyppi 231 oli yleisin sairailla karjuilla (81\%:lla oli tämä haplotyyppi). Tätä haplotyyppiä ei havaittu terveillä karjuilla lainkaan. Kytkentäanalyysissä eri perheissä segregoitui erilaisia haplotyyppejä, mutta kaikilla sairailla yksilöillä oli alleeli 1 haplotyypin viimeisessä markkerilokuksessa. Vertailemalla kaikkien sairaiden haplotyyppejä keskenään voitiin oireen taustalla vaikuttavan geenin sijainti rajata 3 cM:n alueelle kahden markkerin välille. Jotta riittävä erotuskyky markkeriavusteista valintaa ja kandidaattigeenien etsimistä varten saavutettaisiin, täytyi kromosomaalista aluetta rajata (Sironen et al. 2002).

Koska sian kytkentäkartta kyseisellä alueella ei ollut tarpeeksi tiheä, jouduttiin hienokartoitusta varten etsimään uusia markkereja sian BAC-kloonien (bacterial artificial chromosome) avulla. BACklooneihin on liitetty pätkä sian genomia, jonka emäsjärjestys on mahdollista selvittää (sekvensoida) Oireeseen kytkeytyvää aluetta rajaavilla markkereilla valikoitujen BAC-kloonien sisältämää sian genomista emäsjärjestystäverrattiin ihmisen sekvenssitietokantaan. Sialla oireeseen kytkeytynyttä aluetta vastasi 2 Mbp:n alue (2 miljoonaa emäsparia pitkä) ihmisen kromosomissa 5. Yhteistyössä tanskalaisen tutkimuskeskuksen (Danish Institute of Agricultural Sciences, DIAS) kanssa poimittiin heidän tietokannastaan sian sekvenssejä tällä alueella sijaitsevien ihmisen tunnettujen geenien avulla. Näistä sian geeneistä etsittiin sekvenssimuuntelua sekvensoimalla terveitä ja sairaita yksilöitä. Kolmesta geenistä löytyi yksittäisiä emäsmuutoksia ja sairaissa kromosomeissa havaittujen rekombinaatioiden perusteella oire pystyttiin rajaamaan vain muutaman geenin alueelle ihmisen geenikartalla. Näistä yksi, siittiön hännän muodostuksessa ilmenevä geeni, on varteenotettava oireen kandidaattigeeni. Kandidaattigeenin mRNA (geenin tuottama proteiinia koodaava lähettiRNA) sekvensoitiin ja havaittiin yhden eksonin puutos sairailla yksilöillä verrattuna terveisiin. Sairaiden yksilöiden DNA:ta sekvensoimalla löydettiin retrovirusinsertio puuttuvan eksonin jälkeisestä intronista. Sairailta yksilöiltä löydettiin myös toinen virheellisesti silmukoitu RNA tuote, jossa puuttuva eksoni oli mukana, mutta lisäksi siihen oli liitetty osa inserttiä. Nämä molemmat muutokset geenin lukukehyksessä johtavat ennenaikaiseen translaation lopetukseen.

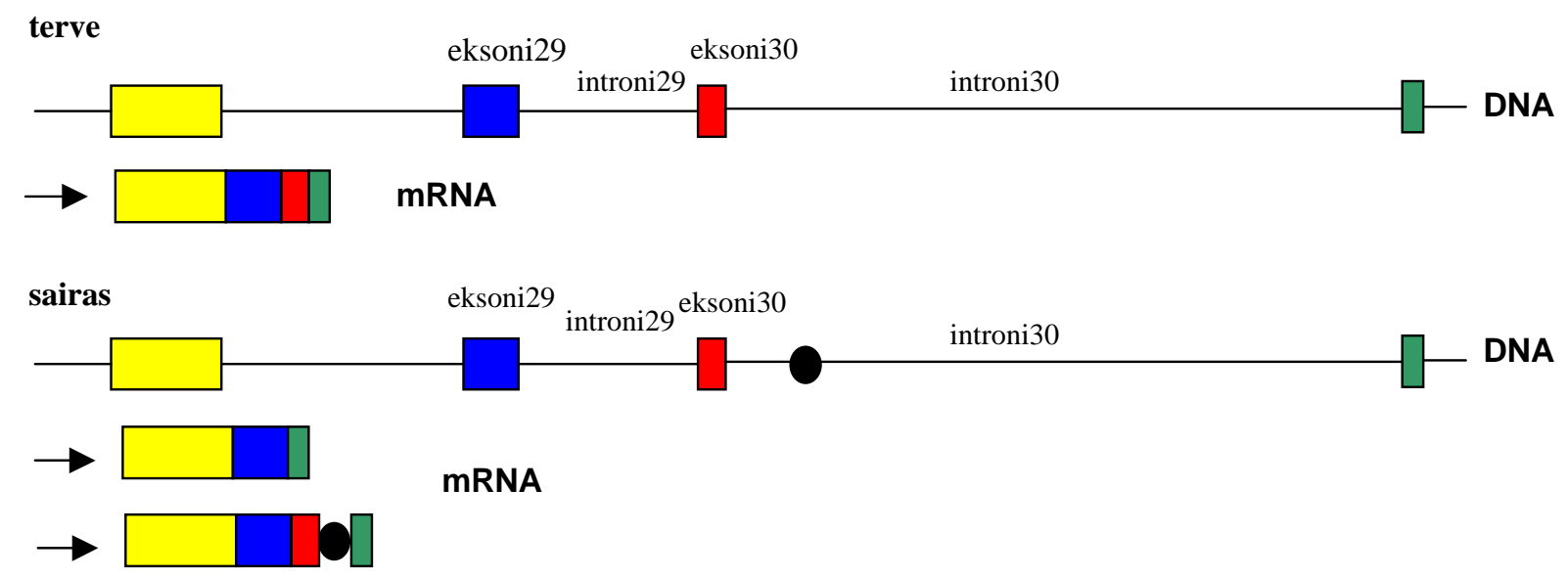

Kuva 1. Retrovirusinsertio siittiöiden puolihäntävian aiheuttavan geenin intronissa 30 johtaa eksonin 30 virheelliseen silmikointiin. Terveillä kontrolliyksilöillä kaikki eksonit liitetään yhteen RNA:n muokkauksessa, mutta sairaiden yksilöiden RNA:sta joko puuttuu eksoni 30 tai eksoni 30:n lisäksi mukaan otetaan osa inserttiä. Musta ympyrä kuvaa introniin liittynyttä retrovirusinserttiä. 
Geenin ekspressiota on myös alustavasti tutkittu ja puuttuva eksoni näyttää ilmentyvän pääasiassa vain testiksessä, mikä on odotettavaa, koska sairailla karjuilla ei havaita muita oireita ja homotsygootit emakot ovat terveitä.

\section{Johtopäätökset}

Tutkimuksessa on osoitettu siittiöiden puolihäntäisyyden suomalaisilla Yorkshire-sioilla johtuvan siittiön hännän kehitysvaiheessa ilmenevään geenin insertoituneesta retroviruksesta. Virus aiheuttaa virheellistä silmukointia yhden eksonin suhteen ja näyttää ilmenevän pääasiassa testiksessä.

Rotalla tehdyn tutkimuksen mukaan siittiöiden puolihäntäoireen taustalla oleva geeni ilmenee rotalla kudoksissa, joissa havaitaan värekarvojen muodostusta (Ostrowski et al. 1999). Tämän tutkimuksen perusteella geeni näyttää olevan tärkeä juuri värekarvan/siittiön hännän kehitysvaiheessa. MTT:ssä tehtyjen alustavien tutkimusten mukaan eri osia geenistä ilmennetään eri kudoksissa. Geenin ilmenemisen tutkimista jatketaan MTT:llä tavoitteena geenin toiminnan ymmärtäminen ja eri kudosvarianttien merkityksen selvittäminen.

Siittiöiden puolihäntäsyndrooman markkeriavusteisessa valinnassa on käytetty kahta oireen kytkeytymisaluetta rajaavaa markkeria valittaessa oireesta vapaita yksilöitä jalostukseen. Markkerit kytkeytyvät tietyllä todennäköisyydellä oireen taustalla olevan geenivirheeseen, mutta eivät ole syy ilmenevään sairauteen. Markkereja käytettäessä testi ei ole $100 \%$ ja tuloksen tulkitsemiseksi tarvitaan myös testattavan yksilön vanhempien näytteet. Osalle testatuista yksilöistä tulosta ei ole voitu määrittää. Kytkeytyneiden markkereiden tyypitys on ollut käytössä vuodesta 2001 alkaen jonka jälkeen kantajien määrä populaatiossa on vähentynyt 38 \%:sta $21 \%$ :iin. Tällä hetkellä geenitesti, joka perustuu oireen aiheuttavaan geeniin insertoituneeseen sekvenssiin, on koekäytössä Fabalabissa (http://www.faba.fi) ja testin pitäisi antaa 100 \%:nen tulos siittiöiden puolihäntäoireen suhteen. Kantajia käytetään edelleen jalostuksessa, mistä johtuen kantajien määrä populaatiossa on säilynyt melko suurena.

\section{Kirjallisuus}

Andersson M., Peltoniemi O., Mäkinen A., Sukura A., Rodriguez-Martinez H. 2000. The hereditary 'Short tail' sperm defect - A new reproductive problem in Yorkshire boars. Reprod Dom Anim 35: 59-63.

Kruglyak L., Daly M., Reeve-Daly M., Lander E. 1996. Prametric and nonparametric linkage analysis: a unified multipoint approach. Am J Hum Genet 58: 1347-63.

Ostrowski L.E., Andrews K., Potdar P., Matsuura H., Jetten A. and Nettesheim P. 1999. Cloning and Characterization of KPL2, a Novel Gene Induced during Ciliogenesis of Tracheal Epithelial Cells. Am. J. Respir. Cell Mol. Biol 20, 4: 675-683.

Sironen A., Andersson M., Uimari P., Vilkki J. 2002. Mapping of an immotile short tail sperm defect in the Finnish Yorkshire on porcine Chromosome 16. Mamm. Genome 13: 45-49. 